\title{
The Existence and Role of Indigenous Food Institution on Strengthening Foods Security of Rural Community
}

\author{
Lalu Wiresapta Karyadi \\ wskaryadi21@gmail.com
}

Department of Social Economics, Faculty of Agriculture, University of Mataram, Indonesia

\begin{abstract}
Local agricultural institutions as an important structure to support the food security system have been marginalized and replaced by formal social institutions that seem foreign to certain communities. This study aims to reveal and explain the existence and role of local agricultural institutions in strengthening the food security of rural communities on the island of Lombok. The research was designed with a qualitative research model. Data collection using several techniques, namely: in-depth interviews, direct observation and literature study. Data analysis used qualitative analysis with interactive models. Analyzes were carried out during data collection and after the end of data collection. The results showed the existence of agricultural institutions in rural areas of Lombok island based on: land control, production processes, provision / utilization of labor, irrigation, harvest and production sharing, storage and distribution of results, the roots of cultural values of the Sasak ethnic community which are the spirit of institutional development of food security are: a sense of togetherness, help to help, peace and peace of life, obedience and decency (the will to build self-image), and harmony in social and spiritual life. The roles and functions of local institutions for the Sasak ethnic community are: Regulating the system of division of labor, distribution of products and income, strengthening social cohesiveness, managing resources, strengthening social participation, building social harmony, and strengthening the food security system.
\end{abstract}

Keywords: Existence, Local Food Institutions, Food Security.

Received: December 27, 2020

Revised: January 24, 2021

Accepted: February 10, 2021

\section{Introduction}

In determining policies to prevent food insecurity and malnutrition, the government often generalizes macro problems into micro problems. Social aspects and local wisdom that develop in the community are not being paid attention to. Food security and nutritional security need to be built based on local resources (Stamoulis, 2001; Cook, 2002; Hamm \& Bellows, 2003). Timmer (2004) argues that the most important challenge today for Indonesia's future food security is to restart rapid and pro-poor growth. An additional challenge to be faced is the "supermarket revolution", which is rapidly changing the basic structure of Indonesia's food marketing system. Horng \& Tsai (2012) explains the need for food development based on local resources which means developing food diversification as a whole. For that, the community must start to be invited back to see local resources, cultivate them and promote them.

Local institutions, local culture and social kinship that have been pillars in creating community harmony really need to be revitalized again. At present, people increasingly do not believe in food and nutrition institutions based on local communities formed by the state during the New Order. Nurjaya \& Nyoman (2007) revealed that local people actually have social capital which can be called local wisdom and traditional institutions in the field of food security and fulfillment of family nutrition. However, social capital and traditional institutions have been abandoned, whereas in many cases, the roles and functions of traditional institutions and social 
capital of local communities are able to provide solutions to various problems of rural poverty, including the problem of food insecurity.

The purpose of this research is to reveal various forms of local community-based institutions, both those that have been developing and those that are still developing, especially those related to food security, tracing the socio-cultural roots of local communities which are the normative spirit of developing local community institutions. related to food security, revealing and explaining the patterns, roles and functions of each element of the institutions of the local community in overcoming the problem of food insecurity

\section{Methods}

To achieve the stated goals, the research is designed in the form of qualitative research (Aminuddin, 2003) with a phenomenological paradigm (Taylor \& Bogdan, 1984). Based on this technique, several data collection techniques were established, namely: semi-structured interviews, in-depth interviews, direct observations, literature studies and focuse group discussions (FGD) (Sutopo, 2003). In the context of this research, researchers or observers act as participants (Buford Junker in Moleong, 2004). In this study, tracing the validity of the data follows four criteria as proposed by Nasution (In Bafadal, 2003) and Moleong (2004), namely: Credibility, Transferability, Dependability and Confirmability.

Data analysis was carried out at two moments, namely (1) analysis during or simultaneously with data collection, and (2) analysis after data collection was completed. Analysis during data collection using a data reduction approach (Data Reduction). Moleong (2004), Bafadal (2003). Data collection during the collection took place following the procedure as proposed by Bogdan and Biklen (In Bafadal, 2003), namely: determining the focus of research, compiling preliminary findings, making plans for subsequent data collection, developing analytic questions, and setting data collection targets. Analyze the data after collection. The steps taken were: developing a system for coding categories, sorting data, presenting data and drawing conclusions.

\section{Results and Discussion}

\section{Existence of Local Wisdom-Based Food Institutions}

The Sasak people on the island of Lombok have a pattern of social relations characterized by a very strong kinship system. One indication is the development of a communal domicile pattern in rural areas, which is commonly known as hut gempeng (hometown) and in a wider orbit the concept of gumi paer (ancestral land) is known. Furthermore, in relation to the sociocultural setting of the Sasak people on the island of Lombok, the social values that are built up from the strong kinship system greatly affect the activities, structures, institutions and social processes that exist in Lombok society. With this social process, the community's life guidelines are strengthened and developed according to the rhythm of life and the characteristics of the environment even though it is limited to its territory (Wibowo et al, 1996). The following are the results of research on local institutions (Indigenous Institutions) related to agriculture and community food security systems that have been or are still developing on the island of Lombok, Indonesia:

\section{Institutional Land Tenure and Production Process}

The land tenure system on the island of Lombok cannot be separated from the power of the Balinese aristocracy Karang Asem which ended in 1894. According to Proreson Van Vollenhoven in Kraan Alfons VD (1956) it was revealed that before the arrival of the Balinese in Lombok there were only small political organizations that transcended village boundaries. , however, in the village there is a form of group which has formed itself, namely: (1) aristocracy 
(upper social strata) - which were originally the prominent villagers; (2) "free" farmers (middle social strata); (3) farm workers (lower social strata).

As with other regions in Indonesia, the island of Lombok also has various local institutions related to agriculture and food security. The results of identification in the research area can be seen about the various institutions, namely:

Sakap System. The sakap system is one of the agricultural production sharing systems that is still developing today. The sakap system developed because of the need for landless farmers to carry out farming activities for their livelihoods. The sakap system that is most widely developed on the island of Lombok to date is sakap with profit sharing called maro (the language of Lombok). Another form of profit sharing related to sakapan is also known as mertelu (divided into three parts or one third of the same). There is a relationship between the land owner and the land cultivator who makes the transaction. In practice, the form of sacrifice for the land owner is only to provide the land itself, while all farm financing is borne by the farmer who manages the land. With the distribution of the cost, the owner and cultivator are entitled to a half share $(50 \%)$ of the results of each. Because of the same division, namely equal parts, the system in Lombok is better known as maro.

The farming production sharing system, including maro, is still developing as a transaction instrument that is widely accepted by the farming community in Puloau Lombok, West Nusa Tenggara. Economically, the practice of the sakap system can be viewed as a distribution of resources that can have an impact on equal distribution of job opportunities and equal distribution of results and income. This means that a number of people who have an agrarian orientation and are part of the farming community but do not own land, then with this system there are still opportunities to work which can ensure food security for their families. A former landlord community leader in Sukamulia Subdistrict, East Lombok Regency, expressed his opinion that: "The sakap system is indirectly a way of sharing sustenance among others, namely the sharing of agricultural production. Many farmers do not own land, but are able to support their families because they are actors in the profit-sharing system of land owned by other people who have large tracts of land. The term is, with one plate there are two or more people who can eat from the same plate".

It seems that the spirit of the profit sharing system or the sakap system originated from the land tenure system in the era of Aristocratic rule in the past. People from the upper class (aristocrats) who have access to land resources generally release their land to be cultivated by others, while they just wait for the portion of the produce delivered by the cultivator. Based on the process that takes place in the sakap system as described above, it shows that the agricultural institutional system plays a very important role in the distribution of agricultural products and the distribution of farmers' income. It is this aspect of the distribution of results that directly helps strengthen the food security system of rural communities in the Indonesian island of Lombok to date.

Pawn systems, leases and the like. Agricultural production-sharing institutions that are still developing on the island of Lombok, Indonesia are the pawn system and the rental system. This system is quite developed in Indonesia, not only regarding land tenure, but also the transfer of control over productive assets or other valuables. Unlike the sakap system, the practice of pawning tends to be more driven by the interests of the land owner. Thus, the bargaining position of land owners tends to be weaker than that of pawn recipients. Each land owner can mortgage his land at a certain value as offered by the recipient of the pledge. Therefore, from 
the past to the present, the value of land pawning cannot be determined with certainty, because the pawn market is largely determined by the needs of the pawner and the pawner.

In the rental system, the bargaining position of land owners and tenants is relatively balanced. Therefore, the rental value of an area of land with a certain class generally has a mutually agreed upon local standard. This system is more directed at meeting the needs of the owner or lessee which is temporary in nature. Farmers on the island of Lombok view the rental or pawning system as an ordinary form of exchange. A person can work on someone else's land simply because the cultivator has a number of resources (money or other service goods) in exchange for the opportunity to cultivate the land for a certain period of time. Based on the process that takes place in the pawning system and the rental system as described above, it shows that the agricultural institutional system plays a very important role in the distribution of agricultural products and the distribution of farmers' income. It is this aspect of yield distribution that directly affects the food security system of rural communities on the island of Lombok, Indonesia.

Annual Land Lease (Naun). Basically this system is another form of rental system. The specifics are: the process of renting land by other people only takes the rainy season (wet month) which in the Sasak language is known as ketaun. So naun or buy taun is taken from the word ketaun which means the rainy season. So, cultivating farmers who only work on the land between the rainy seasons, while the dry season is returned to the land owner. In relation to the development of local institutions, Lombok local farmers are very familiar with the terms selling and buying years. Similar to the system of pawning, rent and the like, this institutional pattern does not directly affect the community's food security system. During its development, it was found in the West Lombok area, that taun buying was meant as a kind of rent for one year. For such an embodiment, it is clear that it is no different from the real meaning of rent. The existence of this annual land lease practice also illustrates the distribution of resource use or agricultural production factors which is one of the processes in the community food security system in rural Lombok Island.

The Right to Cultivate Land for Free (Nyempe 'or Ngingon), is a term for farmers in several areas on the island of Lombok which refers to the granting of rights to cultivate a small portion of land area for free. A relatively large land owner, out of compassion or other social interest, gives people who are deemed less capable of cultivating (utilizing) a small portion of their land. All financing and production results are fully covered and owned by the cultivator (Penyempe '). As a reward, usually "penyempe" takes part in maintaining the farm that is cultivated by the land owner, and is always willing if at any time his energy is needed by the land owner.

Ngingon (this term is better known in the northern part of Lombok) which means "to guard". This ngingon practice is more developed for dry land. In practice: people who receive ingonan (called pengingon) are given the right to utilize (cultivate) other people's dry land, usually among the main crops (main crops) cultivated by the landowner. Pengingon is obliged to take part in guarding (maintaining) and caring for their dry land. Meanwhile, the products from the ingonan plants are not required to hand over to the land owner. Usually, pengingons use the intercropping land with food crops (seasonal crops) as a source of carbohydrates, while the main crops of landowners are usually perennials and other plantation crops.

According to the accounts of a number of informants, in the past ngingon was synonymous with nyakap for dry land, so that in a number of villages, the pengingon was also known as the pengingon. Judging from the distribution aspect of land use and production, this regulation is considered to be closely related to the community's food security system. The indications are: (1) with a higher intensity of land use and increased production of foodstuffs, (2) utilization of production products is generally accepted directly by small farmers who do not have access to

Copyright (C) 2021, International Journal Papier Public Review, Under the license CC BY-SA 4.0 DOI: https://doi.org/10.47667/ijppr.v2i1.73 
land resources. Thus, this system has a clear impact on community food security, in the realm of local food supply. The practice of granting rights to work by land owners to certain farmers also illustrates the distribution of resource use or agricultural production factors, and this is what supports the food security of the people in rural Lombok Island.

\section{Institutions in the Provision / Utilization of Manpower}

Based on the identification results of various local institutions in the agricultural sector, a number of institutions related to labor supply were obtained. The institutions for the provision of manpower that were also still developing in Lombok include:

Mutual Assistance for Agricultural Workers (Besiru). Besiru or besesiru or besiru bales, is a local institution on the island of Lombok which deals with the provision of labor. In terms of language, the verb besiru is the active form of the word siru, which means mutually. That is, mutual assistance, mutual support or mutual support which is based on the spirit and understanding that life requires interaction and sharing with others (Mahyuni, 2009). In its most common implementation, Besiru is mutual assistance or mutual support of workers in doing something, especially agricultural activities by a group of people. Besiru is synonymous with arisan working in agriculture during the ongoing planting season. All informants said that in the past, besiru institutions grew and developed in the rural areas of the island of Lombok. At the beginning of the planting season, usually the besiru system tillage begins to actively carry out its role. Each farmer who belongs to the besiru group jointly helps cultivate the land of certain farmers who are members of the besiru group. Farmers who have a chance to go wrong only bear food which is called ngibukang. On another occasion, members of the Besiru group will work on other farmers' lands, and so on until all of the land of the Besiru members have been processed. Sometimes besiru is also applied to other jobs, such as weeding, harvesting and others. However, as said by the informants, the most common erosures are for land cultivation activities. The principle of joint responsibility or the burden of being shared is highly enforced in erroneous activities.

The development of large agricultural social institutions is motivated by the need for labor which is quite large and the costs are quite expensive. Besiru has economic benefits as an efficient use of costs, especially labor costs for agricultural activities. By making it possible for the member's agricultural land to be managed optimally in each growing season. Thus, these besiru institutions have a relationship with the community's food security system, because the main objective of institutional development is to increase the planting area and ultimately increase overall production.

Land Processing with Livestock (Ngaro). In general, the Sasak people of Lombok Island interpret ngaro as an activity to cultivate rice, especially during the rainy season. However, in fact ngaro (according to a konci informant in Sengkol Village) is an activity of cultivating the land using livestock (buffalo) by herding a group of buffalo tied to one another. The land to be processed first is diary (soaked in water at least one day and night). Stepping on the feet of a group of buffalo will automatically turn and destroy the ground until it is crushed, crumbly and can be planted with rice. In the past, agriculture in southern Lombok could not be separated from buffalo farming. That is why there are many farmers in this area who raise buffalo. Now the Ngaro institutions have not developed at all. According to a number of farmer leaders, the ngaro system has begun to diminish and become lost since the Bimas program began in the seventies. Cultivation activities began to be replaced with a system of plows and hoes.

In the Ngaro system there are principles of cooperation and social solidarity. This is because buffalo owners always combine their buffalo to work on the owner's land in rotation. There are times when the buffalo used by Ngaro is rented by the land owner to the buffalo owner, but in 
the past it was mostly done on the basis of cooperation such as mistaking for bales. Farmers in certain areas admit that this local agricultural system is very helpful for farmers in overcoming difficulties in cultivating labor. Therefore, the ngaro system that once developed on the island of Lombok has contributed to food security in the past.

Loose Wage System and Wholesale System. The daily wage system and piece system are the most developed ways of using labor in agriculture to date. The reduced role of the besiru and ngaro systems has actually been replaced by the wage system (daily an d wholesale). This system places most of the stages of agricultural activity as a market that provides opportunities for labor cost transactions. This system has directly replaced the role of social solidarity with materialistic interests. Therefore, the development of this wage system has directly paralyzed social institutions based on kinship and social solidarity.

From an economic perspective, this labor wage system is actually a form of income distribution in rural areas. With the development of the wage system, agricultural workers have a better bargaining position and have the opportunity to enjoy the results of their labor expenditure, even though within subsistence limits. In a number of villages, the daily wage system tends to decrease and is replaced by a piece system. In the wholesale system, there is a group of farm workers who ask or are asked to work in certain farming activities, such as cultivating the land, planting, weeding or harvesting. For cultivation, weeding and planting, the wage value is determined based on the area of land to be worked on. Wage transactions are usually based on the area of farm land. Meanwhile, for harvests using the threshing system (ngerampek), wages are determined based on the quantity of work produced. These various wage systems seem to strengthen the position of agricultural laborers, so that even distribution of income as the basis for food security can be guaranteed within certain limits.

\section{Irrigation Institutions}

Local institutions in the field of irrigation that have existed on the island of Lombok are Subak. Similar to Bali, subak is a farmer institutional system in terms of agricultural irrigation. Water is considered an important resource in agriculture and its availability is limited so that it needs to be regulated in order to have a better effect on agricultural output. Each subak has a working area (service area) which is known as kesubakan. Even in the past, this fertility became a recognized feature / location of land and was recorded in the ownership mark called pipil. Each sub-district is led by Pekasih or some kind of irrigation agent. It is this pekasih that regulates everything related to the distribution of water.

Judging from the organization, the local institution that has a clear governance system is the subak. Subak membership is registered with Pekasih and Sedahan (land tax collectors). Each member of the subak has clear and defined rights and obligations with the subak member. Their main right is to get irrigation services as needed. The obligation is to pay water fees to Pekasih, known as Suwinih. Later, with the formalization of a number of rural institutions including subak, the suwinih was then converted into an IPAIR (water use fee) managed by the P3A (Water User Farmers Association) which is a subak institutional transformation. The existence of local institutions in irrigation management in turn supported the food security system of rural communities on the island of Lombok before the development of agricultural intensification.

\section{Harvest and Production Sharing Institutions}


Bederep. Based on the meaning of community leaders in general, bederep has a meaning that is identical to labor in agriculture. But the most popular, bederep is intended for harvest labor activities which in Sasak language is called mataq. The term bederep is more commonly referred to as harvest laborers where harvest laborers come from outside the village. These harvest workers are often called Penderep. Penderep usually comes to a village looking for harvest wages (mataq wages) which is usually done on a profit-sharing basis (bawon). The term bederep applies when the harvest is done by means of mataq for head rice. Penderep come to a village with a harvesting tool called rangkap (rice stalk cutting tool).

With regard to harvesting, a system for the results of the harvest between the harvester (penderep) and the land owner was developed, known as Nyolas (eleven). Nyolas is a production sharing system for harvesting activities, where for every eleven parts of the harvest, ten shares for the land owner, and one part for harvest workers (penderep). So for each harvest as many as eleven bunches, then one bunch is the wages given to the harvest laborers. The bederep model developed in the past is considered to be very helpful for the livelihoods of landless farmer families (farm laborers). Because with bederep there is an opportunity for them to get harvest jobs in a number of villages, from these activities they can get a certain amount of rice.

Ngunuh / Mepes. Ngunuh is an activity to take leftover rice from the rice fields after being harvested. In the past, when there was a traditional harvest system there was a habit of people who could not afford to take the leftovers of the rice fruit from the plant. Sometimes the harvest workers (penderep) do not harvest all the plants, but leave the parts that are considered to be not good, such as young fruit or stalks, damaged, empty and the like. By poor communities, the remains are harvested after the official harvest is deemed complete. Sometimes the owner of the rice fields asked the harvesters not to harvest bad products in the hope that the killers could take them. This is intended so that there is a share that can be enjoyed by people other than penderep. The results obtained by the killer are not too much, but usually these results can help improve family food security within certain limits. The term ngunuh developed when the head rice harvesting system was still ongoing.

After the introduction of new (superior) varieties whose harvest is carried out by means of a sickle and shattered to take grain or grain, the ngunuh habit diminishes and in some places the name changes to the term mepes. The principle of mepes is the same as ngunuh, which is to take the remaining portion that has not been harvested. Therefore, the habit of mepes seems to be growing, and there are even groups that travel from one village to another looking for mepes locations. Usually the mepes actors are the family of farm workers who do not have a job. Farmers on the island of Lombok admit that the activity of taking the leftovers of the harvest is very helpful for farm worker families to overcome family food problems on a limited scale. Thus, these local institutions also contributed to food security in the past.

\section{Food Storage and Security Institution}

Carefully investigations have been carried out regarding community food security and storage institutions on the island of Lombok, both those that developed in the past and those that are still developing today. The following describes several institutions aimed at ensuring food security for families and communities in the past and even today.

Food Granary (Banjar Pare). Lumbung (in the sense of a rice storage area in general) which the Sasak people on the island of Lombok have several levels. A community leader in northern East Lombok said that in the past the granary was very instrumental in supporting the food security of rural communities. Because of this vital role in several villages, there are those who oblige every citizen to have a food barn. After verification with the triangulation model, in the 
past on the island of Lombok there were three strata of barns, namely: (1) family / private barns, (2) group / banjar barns, and (3) village barns.

Almost all villages on the island of Lombok in the past had village food barns which functioned as a place to store rice belonging to the village community for various purposes according to the agreement of the community members. In a number of villages on the island of Lombok, the food barn is synonymous with Banjar Pare (rice association). There were differences in the management and use of village granaries between various villages in the past. The differences in management methods involve the limitation of the amount of community contributions / contributions to the village barn, the method of borrowing by the community and the charging system. The following is an example of this difference according to the narrative of an informant from the village of Denggen, East Lombok: "In the past, every harvest season landowners were required to hand over rice to the village barn, each in a segment (4 bunches or 2 Cekel). Land owners whose land is less than one hectare are charged a fee of one Cekel (2 bunches) to be kept in the village barn. When the dry season arrives, the rice in the village barn is distributed to the poor, especially those who do not have a family barn. If there is no famine, farmers can borrow the rice from the village barn to be used as seeds and must be returned after harvesting, as much as borrowed and added with new fees ... and so on, so that the village granary at that time was really useful to ensure the safety of the residents' food. villagers"

A simpler form of this food security institution is the group barn or better known as the banjar. This form is a group usually with a communal living approach called a hut. So another term for this lumbung banjar is lumbung hut (village barn). The management and utilization model of this lumbung banjar / hut is relatively the same as the village barn, only with a more limited scope. Besides that, it is also known as the family barn (Geleng Keluarga). Almost all households in the past had rice storage areas. There are two forms of the family barn, namely: the family barn, which has a larger capacity, is usually owned by a relatively large land-owning family and this is what is commonly called geleng (lumbung). Other forms are smaller ones, have less capacity and are usually owned by underprivileged families, workers or agricultural laborers. This small granary form is commonly called a pantek.

It is also said that in the past (sixty to seventies era) there were restrictions on the intensity of rice harvesting from the village barn, group barn or family barn. Harvesting or unloading (metun pare) of rice from the barn is only permitted once a week in a fixed number of bundles of rice and must be in an odd count (for example 3 bunches, 7 Cekel and the like). This shows that the community must be aware of and willing to apply the principle of frugality in economic expenditure, so that the careful calculation of rice harvest will be sufficient for one week. This accuracy clearly means efficiency so that how much is taken by a particular family and how much is available is automatically recognized by the other community.

Based on the explanation above, it is very clear how central the role of the village barn, granary and family barn is in maintaining food security and meeting people's food needs. However, as stated by Dharmawan et al. (2006), the role of local food institutions in the food security infrastructure system has been replaced by formal institutions which are often not only foreign, but also encounter many obstacles in their operations. This opinion is in line with the assessment of a number of informants, that nowadays the values of togetherness, kinship and affection have faded and are replaced by economic values, material and financial benefits so that mutual cooperation and the like have experienced a significant reduction.

Bedea (Barter System). Bedea is a form of exchange with the in-kind barter system. This institution developed long ago and is still found in several places today. In practice, the pendea (bedea people) usually come from outside the village or outside the village around carrying certain goods, non-rice agricultural products, etc. Then they come to certain houses and offer 
exchanges to the house owners. The exchange that the pendea needs from the host is rice or similar staples. For example: a pendea asks the host to accept the vegetables and the like that is brought and then asks for an unspecified amount of rice (depending on the giver's sincerity). One of the informants said: "In the past, the traveling bedea began to get busy when the dry season arrived, and decreased shortly after the working season (the rainy season) arrived. In terms of benefits, it is clearly a form of food distribution system and supports the community's food security system. It's just that in previous experiences, the status of pendea is often degraded by the community even as being equal with beggars.

However, if there are difficulties in employment and sources of income in rural areas, the practice of bedea appears again, even now the goal is urban areas. Thus, the Bedea is institutionalized as a traditional system of food security and distribution. This is in line with the opinion of Sukesi (2006) which states that in a traditional order, people have local institutions that regulate food security according to their needs.

Zakat (jekat). Ainunnajib, MH (1996) stated that in an atmosphere of social change filled with technology, the echo of zakat, especially in agriculture, is fading. It is revealed from the research results that in the past when the type of rice planted was head rice (tie rice), most farmers always set aside their harvest to pay zakat. The amount is 5 percent of the harvest after cutting the bawon (sharing the harvest with laborers or with the pengakap). One informant in Central Lombok revealed that after harvesting, before the bundled rice was piled (nungkep), 5 bundles of the harvest had to be set aside for the payment of zakat and 2.5 bunches set aside for suwinih (subak fee). The rice owner usually determines himself who will be given zakat from the harvest. While suwinih is given to pekasih (irrigation interpreter / head of subak).

Judging from its substance, it is clear that zakat is a very good distribution system of results and because it is given to poor people and the like, it is clear that this is one of the wisdoms in supporting food security and security in a fair manner. It was admitted by all informants that in the past, there were rarely farmers who did not pay zakat, because there was a belief that if zakat was not paid the yields were not blessed (quickly used up, less useful and the like). The current conditions are somewhat different, since the unhulled rice system developed, the granary does not function as a storage area and most of the grain is sold directly in the fields after harvest. Therefore, it is seldom known that farmers set aside their crops to pay zakat. The wisdom of the past has now diminished so that the strength that arises from the sense of community togetherness has also weakened and food security is largely determined by the market and the government.

Pinch. It is an activity to collect rice by means of pressing (painted with five fingers) or one tablespoon and a similar measure that is set aside by housewives every time they want to cook. The rice that is squeezed is stored in one can or box and at a certain time (for example one month) it is handed over to the association or banjar to then be distributed to the poor, or used for other purposes such as building places of worship and the like. In terms of its essence, this pinch is very useful as a means of food distribution so that it really supports the community's food security program.

There is still a tradition of jimpitan that is still developing today and cannot be seen as a mere social activity, but rather a form of articulation of mutual cooperation culture with the values of togetherness and compassion which is very possible to strengthen social solidarity in society. Dahrul \& Marlianti (2006) argue that the presence of formal food institutions and food distribution mechanisms with a "market mechanism" pattern has marginalized the existence of "native food institutions" which have been supporting the community's food security system.

\section{Basic Cultural Values in Local Institutional Development}


To find out the socio-cultural roots of the local community which are used as the normative spirit of local institutional development in the field of food security, a study has been conducted through in-depth interviews and focus group discussions. The results showed that the development of a number of local institutions was always based on the Sasak community principle value system, namely overlapping. Descriptively the research results are presented as follows:

\section{Togetherness / Solidarity (Desire to share)}

The inherent value of togetherness in various activities of the life of the Sasak people, according to a number of community leaders, is caused by several things: (1) dependence among humans (2) a sense of fate and acceptance, and (3) a willingness to share. Interdependence between people, a sense of the same fate, and a willingness to do this are all solution steps in all problems or difficulties in life in the past. A sense of common fate, for example, seems to have emerged as an icon of social solidarity in the past, especially for marginalized rural communities. One of the expressions (metaphors) of the Sasak people as a reflection of the same fate as a joint, among others (Mahyuni, 2009): Sejari-Jari'n bekerem rice, whose literal meaning is "whatever happens, the rice has been soaked" and the expression with anyong Jari sejukung, literally means "both destroyed / drowned in one boat". The metaphor indicates how the value of togetherness and solidarity is upheld in various social actions. This value is the main asset as stated by Dharmawan et al (2006): loss of social food institutional assets has very significant implications for the food security capacity of the community, especially for communities in isolated areas or households in the lowest social strata (poor) where access to food very bad

With the value of togetherness and driven by other social and economic needs, an institution is built which is initiated and adhered to by the community in order to overcome various problems of life and to achieve social goals in general. Among the institutions whose substance and existence are determined by the value of togetherness, are: besiru, subak, food barn, jimpitan and others.

\section{Compassion and Help (Desire to feel)}

Love and help are actually the manifestation of moral values that exist in members of the social system. Help as a social value arises because there is a moral value in the form of compassion between members of the social system and fellow creatures of God's creation. Thus, helping out is a social moral value that has inspired many social institutions that have been born in rural areas. From the research results, it was found that most of the local social institutions were born from the social moral values of love and help. Among these institutions include: besiru, bederep, ngunuh, food barn (banjar pare), jimpitan and so on.

Besiru, Bederep, banjar pare and the like are expressions of the values of love and help. The value of love and help in the past is the frame of a social process that appears in various social events. In the communal context, these values are said to be very capable and effective in building togetherness and social solidarity. The phrase (metaphor): together with difficulty (equally difficult), together with joy (equally happy), together with good (equally good), together with pain (together in suffering) which means together in joy and sorrow is a description of how The value of compassion and help has built into the attitudes and views of the Sasak people in living communal life in the past, so this is what underlies the emergence of a number of social institutions related to agriculture and food security.

\section{Calm and Peace}

In addition to basic social values, it is found that many local institutions in the agricultural / rural sector are formed from the spirit of economic values (economic interests) solely for the 
growth of a sense of calm and peace in living life. That is, the development of these institutions is more stimulated by interests community economy, so as long as the economic interest is still felt, the institution can actually still exist.

Economic interests are also always connected with inner satisfaction, namely a sense of calm and peace. This value limits the will to want to be alone, greedy and win alone. Phrase (metaphor): Just an araq finger sangonte of worship "(Only if someone is a provision for worship). This expression shows how economic orientation is always linked with spiritual interests, and in this way they find a sense of security, calm and full of peace.

Rural institutions related to the division of labor and production (results) seem to always be based on the existence of economic interests or benefits for members of the community who are involved in these institutions. Among these institutions are: the sakap system, lease and pawning, taun buy, casual wages and the wholesale system, even including the subak. All informants and supervising experts who confirmed the basic value problem of the division of labor and production were of the opinion that the development of such an institution was more motivated by economic interests.

\section{Harmony}

Based on the research results, it is known that the Sasak people prioritize social harmony, so that in most of their actions they always prioritize this harmony value. Social harmony as a goal in every social interaction can be seen from the inspiration of an expression (sesenggak) of the Sasak people who say "mpak smell, aik meneng, tunjung tilah" (fish are obtained, water remains clear, and the lotus tree remains intact). Its meaning freely is: goals are achieved, social harmony is maintained, and the environment is maintained. This expression is seen as a philosophy of life for the Sasak people that contain values of struggle, harmony and harmony with nature. Based on the results of identification and context analysis, it is known that a number of institutions are mainly built and developed from the existence of the values of harmony and harmony, namely: bederep, subak, food storage, zakat and others.

\section{Obedience and Compliance}

Another noble value which is also the spirit of the growth and development of local institutions in the past is "compliance and propriety". Obedience refers more to the concept of a transcendent relationship between humans and God. In other words, this obedience is closer to the meaning of devotion or obedience to carry out religious orders. Thus, obedience in society's assessment is the context of human relations with God which is directed by religious regulations (Fiqh) to be able to worship as well as possible, while 'appropriateness' is the context of human relationships with fellow humans or other God's creatures as shown by attitudes and actions (morals) in society.

Based on the results of careful supervision, it turns out that there is only one institution related to agriculture and food security that is imbued with the values of compliance and propriety, namely Zakat. As stated by Ainunnajib in Akmaliyah (2017) that in fact zakat is a religious institution which is automatically a social institution. Outside the context of agriculture and food security, there are many social institutions that grow and develop the values of compliance and appropriateness, such as the yasinan group, the kelem group, the dhikr group and so on. The importance of zakat in terms of human welfare was stated by Abdullah \& Suhaib, 2011 and the same thing was stated by Ibrahim (2015) that Zakat is a special obligation in releasing a portion of individual wealth for social good. Zakat has the potential for the welfare of the people if it is optimally empowered. Because, the sources of zakat that exist in Muslims are very many forms and the amount is also very large. 


\section{Conclusion}

The existence and development of local institutions related to food security in rural areas of the island of Lombok are generally based on several domains of community activity, namely land control, production processes, provision / utilization of labor, irrigation (irrigation and drainage), harvest and profit sharing, storage and distribution. the result. The roots of the cultural values of the Sasak ethnic community which are the spirit of growth and development of local institutions including in the field of food security are a sense of togetherness / solidarity (willingness to share), love / help (the will to feel each other), peace and peace of life obedience and appropriateness (the will to build self-image), harmony in social and spiritual life. The role and function of local institutions for the Sasak ethnic community on the island of Lombok is a vehicle and arrangement for the division of labor, as an effort to distribute production and income, as a means of strengthening social cohesiveness and solidarity, a vehicle for regulating resource use, as a way of strengthening social awareness and participation, building social harmony with fellow humans, nature and God, and as a vehicle for and strengthening the food security system.

\section{References}

Alfons V. D. K. (1956). Lombok Takluk dan Terjajah terjemahan Lombok Concuest and Decolonization. Mataram: Pusat Studi Pembangun Nusa Tenggara Barat.

Bafadal, I. (2003). Teknik Analisis data Penelitian Kualitatif dalam Metodologi Penelitian Kualitatif, Tinjauan Teoritis dan Praktis. Malang: Universitas Islam Malang dan Visi Press.

Cook, J. T. (2002). Clinical implications of household food security: definitions, monitoring, and policy. Nutrition in Clinical Care, 5(4), 152-167.

Dahrul S. \& Sri Anna M., (2006). Aspek teknologi dalam Rekosntruksi Kelembagan Sosial Penanganan dan Pencegahan Rawan Pangan dan Gizi Buruk dalam Proseding Lokakarya Nasional II Penganekaragaman Pangan. Forum Kerja Penganekaragaman Pangan, PT. Indofood Sukses Makmur Tbk dan Bogasari Flour Mills.

Dharmawan, Arya H. \& Rilus Kinseng, (2006). Aspek Sosial Budaya dalam Rekonstruksi Kelembagaan Sosial Penanganan dan Pencegahan Rawan Pangan dan Gizi Buruk dalam Proseding Lokakarya Nasional II Penganekaragaman Pangan. Forum Kerja Penganekaragaman Pangan, PT. Indofood Sukses Makmur Tbk dan Bogasari Flour Mills.

Hamm, M. W., \& Bellows, A. C. (2003). Community food security and nutrition educators. Journal of Nutrition Education and Behavior, 35(1), 37-43.

Horng, J. S., \& Tsai, C. T. (2012). Culinary tourism strategic development: an Asia-Pacific perspective. International journal of tourism research, 14(1), 40-55.

Mahyuni, (2009). Kebudayaan Sasak dalam Perspektif Linguistik. Universitas Mataram, Pidato Pengukuhan Guru Besar tetap Universitas Mataram, Mataram.

Moleong, L. J., \& Edisi, P. R. R. B. (2004). Metodelogi penelitian. Bandung: Penerbit Remaja Rosdakarya.

Nurjaya \& Nyoman I, (2007), Otonomi Daerah : Menuju Tata Hukum Daerah Yang berbasis Kearifan Lokal, dalam Pengelolaan Sumberdaya Alam dalam Perspektif Antropologi Hukum. Program Studi Hukum Program Pascasarjana Unibraw dan UM Press Malang. 
Stamoulis, K. G. (Ed.). (2001). Food, agriculture, and rural development: current and emerging issues for economic analysis and policy research. Food \& Agriculture Org.

Taylor, S. J., \& Bogdan, R. (1984). Introduction to qualitative research methods: The search for meanings. Wiley-Interscience. 